Journal of the Rubber Research Institute of Sri Lanka (2019) 99, 47-56

\title{
Poverty alleviation through improvement in technical efficiency in the smallholder rubber sector: case study from Kegalle District of Sri Lanka
}

\author{
P G N Ishani*, Wasana Wijesuriya* and J K S Sankalpa* \\ * Rubber Research Institute of Sri Lanka, Dartonfield, Agalawatta, Sri Lanka
}

\begin{abstract}
Growth and development of the agriculture sector play an important role in the alleviation of poverty. There is a long-lasting debate on whether improvement in efficiency levels leads to eradicate poverty. Further, some studies unveiled that farm and farmer characteristics have a significant influence on poverty. Hence, this study attempts to examine the relationship between technical efficiency and poverty and the effect of farmer's characteristics on poverty levels among the smallholder rubber farmers in Kegalle District.

Data were collected from 195 smallholder rubber farms in Kegalle district through a questionnaire survey. Cobb-Douglas Stochastic Frontier Analysis (SFA) was employed to determine the Technical Efficiency (TE) of the farmers and Poverty Gap Index (PGI) was calculated to measure the depth of poverty in the sample. Correlation analyses were conducted to analyze the relationship between poverty and technical efficiency. Generalized Linear Model (GLM) was employed to determine the farm and farmer characteristics affecting poverty.

The estimated mean technical efficiency of smallholder rubber farmers in Kegalle district was $63 \%$, implying that the natural rubber production could be increased further by $37 \%$ through better use of existing resources and technology. Correlation analysis indicated that TE has a significant negative correlation $(r=-0.147, P=0.04)$ with poverty, indicating that improving TE will help to alleviate poverty.

Results of GLM model indicated that years of education of the farmer and the farm size have a strong negative influence on poverty while family size and age of the farmer have a positive association with poverty. Hence, policymakers should give more consideration to these factors in poverty alleviation programmes.
\end{abstract}

Key words: Cobb-Douglas Stochastic Frontier Analysis, correlation analysis, generalized linear model, poverty, smallholders, technical efficiency

\section{Introduction}

Natural Rubber (NR) is one of the major contributors to the Sri Lankan economy which generates an export revenue of more than US\$ 1 billion according to the statistics. About $68 \%$ of NR is provided by the smallholder sector in Sri Lanka. Kegalle District has the highest NR land area followed by Ratnapura, Kalutara, Gampaha, and Colombo districts. The 
NR production of the country has recorded as 82,000 tonnes in the year 2017, which has been in a slightly up and down movement (Anon, 2017a).

The NR production of the country remains as quite steady state during the last few years, yet considerably low with respect to the area under tapping. This is one of the major concerns in the Sri Lankan rubber sector. The overall productivity in the country is around 800 $\mathrm{kg} / \mathrm{ha} /$ year, which is far behind the countries like Vietnam, India and Malaysia where the yields average around 1680,1431 and $1400 \mathrm{~kg} / \mathrm{ha} /$ year, respectively (Anon., 2016a; Anon., 2016b).

The low productivity may lead to loss of a considerable amount of potential income, which makes the smallholder rubber sector an uncompetitive venture (Kumarasinghe et al., 2012). Further low rubber prices and low productivity levels of rubber lands push small scale rubber farmers into poverty (Anon., 2016c). In attempting to enhance the productivity of existing lands, one crucial aspect is increasing efficiency which can be measured in terms of technical efficiency (Kumarasinghe et al., 2012). Technical efficiency can be defined as the ability of firms to produce the maximum possible output level from a given set of inputs and technology (Kumbhakar et al., 2015).

Socio-economic characteristics of households have a significant influence on the poverty status of the household. Age, farm size, farm experience, years spent in school, family size, gender and dependency ratio are the key socioeconomic variables that should be critically considered in the poverty alleviation programmes (Umeh et al., 2013; Omoregbee et al., 2013).

As most of the rural people depend on agriculture for their livelihood, farm productivity improvement through increasing technical efficiency is one of the major policy decisions taken to alleviate poverty. At a given level of inputs, a producer is said to be technically inefficient if he is unable to produce the maximum possible output level. Hence, improvement in technical efficiency will increase farm income and reduce poverty (Islam and Haider, 2018). There is a longstanding discussion about the effect of technical efficiency and factor productivity on poverty alleviation. Many scholars show evidences in favour of an inverse relationship between efficiency and poverty, while some of the studies indicate that technical efficiency is not sufficient in poverty reduction or there is no significant relationship between technical efficiency and poverty (Gelaw, 2013; Asogwa et al., 2012; Islam and Haider, 2018).

There is little empirical evidence of the relationship between technical efficiency and poverty among the smallholder rubber farmers in Sri Lanka to guide agricultural policies that aimed towards alleviation of poverty among the rural farmers. Further, it is important to identify the farm and farmer characteristics of smallholder rubber farmers that affect poverty. Hence this study attempts to examine the relationship between technical efficiency and poverty among the smallholder rubber farmers and the smallholder 
P G N Ishani et al.

rubber farm and farmer characteristics that affect the poverty in Kegalle District, which can be exploited as a basis for poverty alleviation strategy.

\section{Methodology \\ Study area}

The study area lies between $80^{\circ} 20^{\prime} \mathrm{E}$ Longitudes and $7^{\circ} 14^{\prime} \mathrm{N}$ Latitudes. Kegalle District was purposefully selected for the study as it is one of the major rubber growing areas in Sri Lanka where rubber market channels are well established. This district has an extent of 28,765 ha of rubber which is around $30 \%$ of the total rubber extent in Sri Lanka. The number of smallholdings in this area is about 24,309 with a total extent of 16,959 ha. (Anon, 2016b). Contribution to total poverty from the Kegalle District is $7.2 \%$ and the number of poor people in the District is 60,435 out of 869,000 total population. Hence, around $6 \%$ of the total population in Kegalle District is suffering from poverty. Further, the Head Count Index (HCI) and Poverty Gap Index (PGI) in Kegalle District are $7.1 \%$ and $1.1 \%$, respectively (Anon., 2017b).

\section{Sample selection and data collection}

Randomly selected 195 smallholdings stratified according to the number of holdings in each Divisional Secretariat (DS) were used in the survey. The farmers were interviewed through a structured questionnaire to collect primary data.

\section{Frontier analysis}

The frontier production function methodology has been extensively used in production economics to estimate technical efficiency due to its strong theoretical background (Kumbhakar et al., 2015). The stochastic frontier approach was selected for this study, as this method allows for statistical noise (Bravo-Ureta et al., 2007). The CobbDouglas functional form was used to estimate the production function as it satisfies homogeneity condition and allow to estimate returns to scale and elasticity coefficients relatively easier (Coelli et al., 1998). The following Cobb-Douglas production function was used in the analysis.

$\operatorname{Ln} Y_{i}=\beta 0+\beta 1 \ln \left(X_{1 i}\right)+\beta 2 \ln \left(X_{2 i}+\beta 3\right.$ $\ln \left(\mathrm{X}_{3 \mathrm{i}}\right)+\beta 4 \ln \left(\mathrm{X}_{4 \mathrm{i}}\right)+\mathrm{Vi}-\mathrm{Ui}$

Where,

$Y_{i}$ - Dry rubber production of the $i^{\text {th }}$ firm (kg/year),

$\mathrm{X}_{1 \mathrm{i}}$ - Extent of the Land (ha)

$\mathrm{X}_{2 \mathrm{i}}$ - Labour (Man Days/year)

$\mathrm{X}_{3 \mathrm{i}}$ - Quantity of fertilizer used ( $\mathrm{kg} /$ year),

$\mathrm{X}_{4 \mathrm{i}}$ - Chemicals used (L/year)

$\mathrm{V}_{\mathrm{i}}$ - Error component which stands for the random output variations

$\mathrm{U}_{\mathrm{i}}$ - Technical inefficiency relative to the stochastic frontier

In order to determine the farm and farmer-specific attributes influencing the technical inefficiency of smallholder rubber farmers, the following model was formulated and estimated together with the stochastic frontier model in a singlestage maximum likelihood estimation procedure. 
Technical efficiency and poverty incidence

$\mathrm{U}_{\mathrm{i}}=\delta_{0}+\delta_{1} \mathrm{Z}_{1}+\delta_{2} \mathrm{Z}_{2}+\delta_{3} \mathrm{Z}_{3}+\delta_{4} \mathrm{Z}_{4}+\delta_{5} \mathrm{Z}_{5}$

$+\delta_{6} \mathrm{Z}_{6}$

$\mathrm{N}$-Total population

Where,

$\mathrm{Z}_{1}=$ Education (Years)

$\mathrm{Z}_{2}=$ Labour involvement from family (number)

$\mathrm{Z}_{3}=$ Experience (years)

$Z_{4}=$ Dummy for Adoption of Extension Services (1-Yes, 0-No)

$\mathrm{Z}_{5}=$ Dummy for Management of the Farm (1-Owner, 0-Care Taker)

$\mathrm{Z}_{6}=$ Dummy for Method of Harvesting (1-By family, 2-Hired Labour)

The software FRONTIER 4.1 was used to estimate technical efficiency values and determinants of efficiency jointly as described by Coelli (1996). The 'zeros' in the Cobb-Douglas model was handled as described by Battese (1996).

\section{Correlation analysis between poverty and technical efficiency}

A correlation analysis was conducted to analyze the relationship between poverty and technical efficiency. Poverty or income gap index was calculated to measure the depth of poverty in the sample. This measures the extent to which individuals fall below the poverty line (the poverty gaps) as a proportion of the poverty line (Asogwa et al., 2012). The official poverty line by district, which is calculated by the Department of Census and Statistics Sri Lanka was considered in the calculations (Anon., 2016d). The poverty gap index (P) can be written as,

$\mathrm{P}=\frac{1}{N} \sum_{i=1}^{N} \frac{(z-y i)}{z}$

where,

Z - Poverty line

$\mathrm{y}_{\mathrm{i}}$ - Monthly income of the farm families

\section{Determinants of poverty}

Generalized linear model (GLM) was employed to identify the farm and farmer characteristics that affect poverty as a means of overcoming the assumptions of linearity and equal variance in Ordinary Least Square regression. Further GLM uses maximum likelihood estimation to estimate parameters which are more accurate compared to ordinary least squares (Nelder and Wedderburn, 1972). The following generalized linear model (GLM) was used to measure the effect of farm and farmer characteristics on poverty.

$$
\begin{aligned}
\mathrm{Yi}= & \beta_{0}+\beta_{1} \mathrm{X}_{1 \mathrm{i}}+\beta_{2} \mathrm{X}_{2 \mathrm{i}}+\beta_{3} \mathrm{X}_{3 \mathrm{i}}+\beta_{4} \mathrm{X}_{4 \mathrm{i}}+ \\
& \beta_{5} \mathrm{X}_{5 \mathrm{i}}+\beta_{6} \mathrm{X}_{6 \mathrm{i}}+\varepsilon_{\mathrm{i}}
\end{aligned}
$$

Where,

$\mathrm{Y}_{\mathrm{i}}$ - Poverty gap index

$\mathrm{X}_{1}-$ Gender

$X_{2}-$ Age (years)

$\mathrm{X}_{3}$ - Dependency Ratio (sum of household members below 14 and above 65 divided by the total number of household members)

$\mathrm{X}_{4}$ - Education (Years)

$\mathrm{X}_{5}-$ Experience (Years)

$\mathrm{X}_{6}-$ Family Size

$\mathrm{X}_{7}-$ Farm Size (ha)

$\varepsilon_{\mathrm{i}}$ - error term

\section{Results and Discussion}

\section{Analysis of technical efficiency}

The summary statistics of the variables used in the stochastic frontier model and inefficiency model are presented in Table 1. 
P G N Ishani et al.

Table 1. Descriptive statistics of variables used in the stochastic frontier model

\begin{tabular}{lrrrr}
\hline Variable & Mean & $\begin{array}{l}\text { Standard } \\
\text { deviation }\end{array}$ & Minimum & Maximum \\
\hline Variables used in Production Model & & & & \\
Dry rubber yield (kg/year) & $1,048.05$ & 671.46 & 150 & 3,500 \\
Labour (Man days/year) & 144.37 & 41.48 & 68 & 314 \\
Fertilizer (kg/year) & 119.06 & 146.29 & 1 & 641 \\
Land area (ha) & 0.86 & 0.51 & 0.20 & 2.02 \\
Chemicals (L/year) & 41.52 & 343.49 & 1 & 3,901 \\
Variables used in inefficiency model & & & & \\
Labor involvement from family (Number) & 4 & 1.44 & 1 & 5 \\
Experience (Years) & 20.31 & 8.01 & 7 & 40 \\
\hline
\end{tabular}

The majority of the farmers in the sample $(42 \%)$ have studied up to ordinary level, while $27 \%$ of the farmers have primary education, $26 \%$ studied up to advanced level and about $6 \%$ of the sample farmers had higher education qualifications. The majority of the farmers $(87 \%)$ have adopted the knowledge gathered from extension services. More than $90 \%$ of the rubber lands are managed by the owner of the land. While $44 \%$ of the farmlands are harvested by the family members, $56 \%$ of lands were harvested through hired labour. The mean experience level of farmers in the sample is 20 years which ranged from 7 to 40 years. The maximum likelihood (ML) estimates of the Cobb-Douglas stochastic frontier parameters and inefficiency model are given in Table 2.

Table 2. Maximum likelihood estimates of Cobb-Douglas Stochastic production frontier

\begin{tabular}{lrrr}
\hline Variable & Coefficient & Std. Err & t-value \\
\hline Stochastic production frontier & & & \\
Ln (labour) & 0.731 & 0.104 & $7.025^{* * *}$ \\
Ln (Fertilizer) & -0.014 & 0.012 & -1.117 \\
Ln (Land area) & 0.333 & 0.054 & $6.171^{* * *}$ \\
Ln (Chemicals) & -0.056 & 0.132 & -0.424 \\
Constant & 4.473 & 1.154 & 3.876 \\
Inefficiency effects & & & \\
Education & -0.211 & 0.066 & $-3.188^{* *}$ \\
Family members & 0.000 & 0.024 & 0.003 \\
Extension & 0.110 & 0.098 & 1.125 \\
Experience & -0.029 & 0.006 & $-5.12^{* * *}$ \\
Management & 0.044 & 0.111 & 0.399 \\
Harvest & -0.009 & 0.041 & -0.228 \\
Constant & -0.665 & 1.352 & -0.490 \\
Variance parameters & & & \\
Sigma squared & 0.12 & & \\
Gamma & 0.66 & & \\
Log Likelihood function & $* * *$ significant at 1\% level ** significant at 5\% level & \\
\hline \multicolumn{2}{l}{}
\end{tabular}


The estimate of $\gamma$ is 0.66 , which indicates that only $66 \%$ of the total variation in dry rubber output was due to technical inefficiency and this satisfied the theory that the true $\gamma$ should lie between zero and one. The estimated ML coefficient of labour showed a positive value of 0.731 which is statistically significant at $1 \%$ level. Similar results were obtained by Basnayake and Gunaratne (2002) and Wijesuriya et al. (2012). The estimated ML coefficient of land area showed a positive value of 0.333 which was significant at $1 \%$ level. These findings are also in line with Basnayake and Gunaratne (2002), Barnes (2008), Wijesuriya et al. (2012) and Fatima et al. (2016). The ML estimates of fertilizer and chemicals are not statistically significant. However, an increment of number of labour units and land area by one unit will increase the dry rubber output by 0.731 percent and 0.333 percent, respectively.

The effect of farm and farmer specific factors on inefficiency was simultaneously estimated with the production frontier. The estimated coefficients in the inefficiency model are presented in Table 3 . The coefficient for education is negative and statistically significant at 5\% level indicating that the educated farmers are more efficient compared to others. This result is consistent with Bettese et al. (1996), Basnayake and Gunaratne (2002), Wijesuriya et al. (2012) and Fatima et al. (2016). The coefficient for experience was also found to be negative and statistically significant at $1 \%$ level. This suggests that experienced farmers are more efficient compared to less experienced ones. This result confirms that of Fatima et al. (2016).

Accordingly, experience and education are the key factors affecting the technical efficiency of rubber smallholders. The other variables; viz. labour involvement from family, adoption of extension services, type of management and method of harvesting are not statistically significant. The frequency distribution of the estimated technical efficiency of rubber smallholders is given in Figure 1.

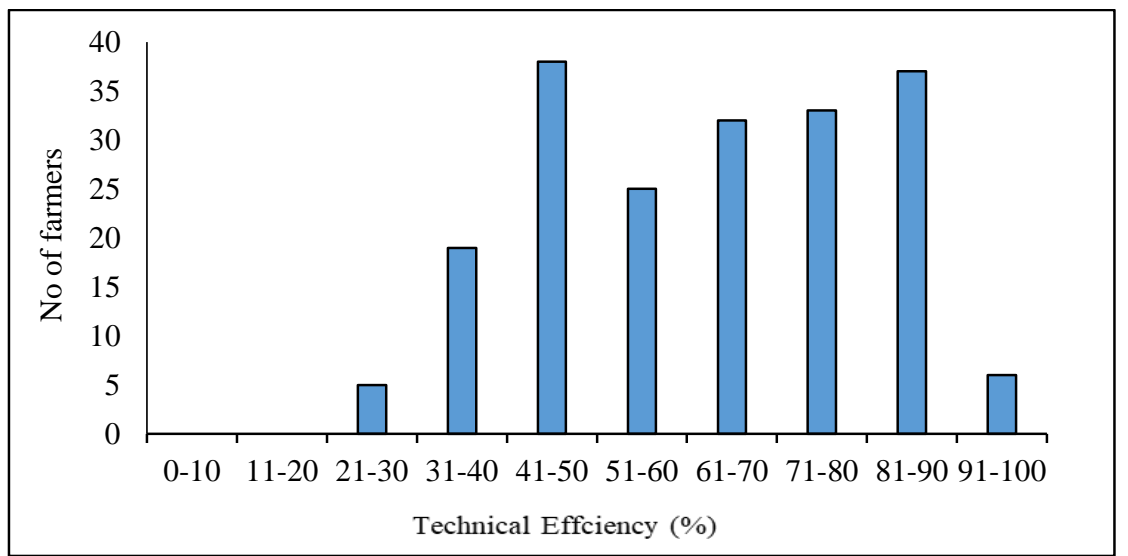

Fig. 1. Distribution of technical efficiencies (based on Cobb-Douglas specification) 
P G N Ishani et al.

The results revealed that the technical efficiencies estimated using CobbDouglas production frontier ranged from $21 \%$ to $92 \%$. The mean technical efficiency in the sample is 63\% indicating that $37 \%$ of the potential maximum productivity is lost due to technical inefficiency of the farmers in Kegalle District. Hence, there is a possibility to increase the TE further by $37 \%$. Around $51 \%$ of farmers in the sample have TE higher than the average value of $63 \%$. A relatively higher percentage of farmers was observed in the range of $41-50 \%$. Whilst $3 \%$ of the farmers had efficiency levels higher than $90 \%$, there were around $30 \%$ of the sample had technical efficiency of less than $50 \%$.

Poverty status of the smallholder rubber farmers in Kegalle District

The minimum expenditure per person per month in Kegalle District in 2016 was Rs.4,073.00. It was observed that there were only 35 households out of total 195 households in the sample were found below this official poverty line.

\section{Farm and farmer characteristics affecting poverty}

The results of the GLM is presented in Table 3.

This GLM has a reasonable model fit with a $\mathrm{R}^{2}$ value of $33 \%$. Results of the GLM indicate that years of education of the farmer and farm size has a significant negative relationship with the poverty gap index.

It suggests that increasing farm size and improving the education level of the farmer helps to reduce the poverty level of farmers. Further, family size and age of the farmer have a significant positive association with the poverty gap index. Hence, increased family size and age of the farmer tends to increase the poverty level of farmers. However, gender, experience and dependency ratio do not have a significant relationship with the poverty gap index.

Table 3. Effect of household variables on Poverty Gap Index

\begin{tabular}{llllllc}
\hline Variable & Coefficient & $\begin{array}{l}\text { Std. } \\
\text { Error }\end{array}$ & $\mathbf{Z}$ & $\mathbf{P}>|\mathbf{z}|$ & [95\% Conf. Interval] \\
\hline Gender & 0.071 & 0.169 & 0.420 & 0.672 & -0.260 & 0.403 \\
Dependency Ratio & -0.046 & 0.059 & -0.780 & 0.434 & -0.161 & 0.069 \\
Education & -0.171 & 0.069 & -2.470 & $0.013 * *$ & -0.307 & -0.036 \\
Family Size & 0.387 & 0.071 & 5.450 & $0.000^{* * *}$ & 0.248 & 0.525 \\
Age & 0.101 & 0.058 & 1.740 & $0.082^{*}$ & -0.013 & 0.214 \\
Farm Size & -0.206 & 0.078 & -2.630 & $0.009 * * *$ & -0.359 & -0.052 \\
Experience & -0.105 & 0.080 & -1.310 & 0.191 & -0.261 & 0.052 \\
Constant & -0.056 & 0.155 & -0.360 & 0.718 & -0.360 & 0.248 \\
\hline \multicolumn{6}{c}{$* * *$ Significant at 1\% level, ** Significant at 5\% level, *Significant at 10 \% level }
\end{tabular}


Correlation analysis between technical efficiency and poverty

According to the results of correlation analysis, there is a significant negative $(\mathrm{r}=0.1478, \quad \mathrm{P}=0.0402) \quad$ relationship between technical efficiency and poverty gap. Thus, there exists an inverse relationship between poverty and technical efficiency. These results are in line with the results of Gelaw (2013), Asogwa et al. (2012a) and Asogwa et al. (2012b).

\section{Conclusion}

The mean technical efficiency level in the sample is around 63\%. Further, the technical efficiency in the sample ranged between $21 \%$ and $92 \%$. Therefore, there is a possibility to increase the output level by $37 \%$ without any increase in the level of outputs. From the farm and farmer specific characters, farmer's experience and education have a negative relationship with the technical inefficiency. This suggests that more experienced farmers are more efficient compared to the newcomers. Hence it is necessary to conduct farmer training programs especially focusing on the newcomers to improve their exposure to the rubber management practices. Further, farmers with higher educational levels are more efficient compared to those with low educational levels. This may be due to the increased knowledge levels through education which probably help them to take appropriate managerial decisions. Thus, improving education facilities in the area will help to increase the efficiency levels of the farmers.

According to the poverty analysis and the poverty level, there are 35 smallholders below the official poverty line. Poverty determinant analysis reveals that the farmer's education, farm size, age of the farmer and the family size of the farmer has a significant influence on the poverty level. Hence, policymakers should critically consider these factors in poverty alleviation programmes.

Results of correlation analysis indicate that technical efficiency has a significant negative correlation with poverty. Hence, this study unveils that improving the technical efficiency of the farm will reduce the poverty level of farmers. As the education level and the experience have a significant positive impact on the technical efficiency of the farmers, the awareness of farmers on rubber cultivation and management practices needs to be improved through effective means of technology transfer. Adoption of these practices will eventually increase the productivity of smallholder lands and reduce the poverty levels of the farmers.

\section{Acknowledgements}

The authors are grateful to the Head, Advisory Services Department and his staff for assisting in the collection of data and the smallholder farmers in Kegalle district for their support during the questionnaire survey.

\section{References}

Anon. (2016a). Annual Report. Central Bank of Sri Lanka.

Anon. (2016b). Statistical Information on Plantation Crops. Ministry of Plantation Industries. $11^{\text {th }}$ Floor, Sethsiripaya Stage II, Battaramulla. 
P G N Ishani et al.

Anon. (2016c). Low prices drive natural rubber producers into poverty. An overview of sustainability issues and solutions in the rubber sector. Fair Rubber Association, Cologne/London, Sustain, Burlington VT.

Anon. (2016d). Household Income and Expenditure Survey - 2016. Ministry of National Policies and Economic Affairs and Sri Lanka (2016). http:// www. statistics. gov.lk/HIES/HIES2016/ HIES2016_FinalReport.pdf

Anon. (2017a). Statistical Information on Plantation Crops. Ministry of Plantation Industries. 2016. $11^{\text {th }}$ Floor, Sethsiripaya Stage II, Battaramulla.

Anon. (2017b). Poverty Indicators, Household Income and Expenditure Survey 2016. Department of Census and Statistics, Ministry of National Policies and Economic Affairs and Sri Lanka. pp.1-4.

Asogwa, B C, Umeh, J C and Okwoche, V A (2012a). Estimating the determinants of poverty depth among the peri-urban farmers in Nigeria. Current Research Journal of Social Sciences 4(3), 201-206.

Asogwa, B C, Umeh, J C and Okwoche, V A (2012b). Poverty and efficiency among the farming households in Nigeria: A Guide for Poverty Reduction Policy. Current Research Journal of Economic Theory 4(1), pp. 6-10. Available at: http://maxwellsci.com/print/ crjet/v4-610.pdf.

Barnes, A (2008) Technical Efficiency Estimates of Scottish Agriculture:A Note. Journal of Agricultural Economics 59(2), pp. 370-376. doi: 10.1111/j.14779552.2008.00156.x.

Basnayake, B M J K and Gunaratne, L H P (2002). Estimation of technical efficiency and its determinants in the Tea Small Holding Sector in the Mid Country Wet Zone of Sri Lanka. Sri Lankan Journal of Agricultural Economics 4(1381-
2016115740), pp. 137-150.

Battese, G E, Malik, S J and Gill, M A (1996). An investigation of technical inefficiencies of production of wheat farmers in four districts of Pakistan. Journal of Agricultural Economics 47(14), pp. 37-49. http://dx.doi.org/10.1111/j.14779552.996.tb00670.x.

Bravo-Ureta, B E, Solís, D, López, V H M, Maripani, J F,Thiam, A and Rivas, T (2007). Technical efficiency in farming: a meta-regression analysis. Journal of Productivity Analysis 27(1), pp. 57-72.

Coelli, T J (1996). A guide to FRONTIER version 4.1: a computer program for stochastic frontier production and cost function estimation. CEPA Working papers 7, 1-33

Coelli, T, Rao, D S P and Battese, G (1998). An introduction to efficiency and productivity analysis. Boston: Kluwer Academic Publishers. http://dx.doi.org/ 10.1007/978-1-4615-5493-6.

Fatima, H, Khan, M A, Zaid-Ullah, M, Abdul-Jabbar, and Saddozai, K N (2016). Technical Efficiency of Cotton Production in Pakistan: A Comparative Study on Non BT and BT-Cotton Farms, Sarhad. Journal of Agriculture 32(4), pp. 267-274.

Gelaw, F (2013) Inefficiency and incapability gaps as causes of poverty: a poverty line-augmented efficiency analysis using stochastic distance function. African Journal of Agricultural and Resource Economics 8(2), pp. 24-68.

Islam, M S and Haider, M Z (2018). Poverty and technical efficiency in presence of heterogeneity in household behaviours: Evidence from Bangladesh. International Journal of Social Economics 45(11), pp.1490-1514.

Kumbhakar, S, Wang, $\mathrm{H}$ and Horncastle, A (2015). Frontmatter. In A Practitioner's Guide to Stochastic Frontier Analysis 
Using Stata (pp. I-Iv). Cambridge: Cambridge University Press.

Kumarasinghe, $\mathrm{H}$, Edirisinghe, $\mathrm{J} \mathrm{C}$ and Patalee, M A B (2012). Role of human capital in efficiency increases : evidence from a data envelopment analysis of rubber smallholdings in Gampaha district. Journal of the Rubber Research Institute of Sri Lanka 92, pp. 12-21.

Nelder, J and Wedderburn, R W (1972). Generalized Linear Models. Journal of the Royal Statistical Society. Series A (General) (Blackwell Publishing) 135(3), pp. 370-384. doi:10.2307/2344614. JSTOR 2344614.

Omoregbee, F E, Ighoro, A and Ejembi, S A (2005). Analysis of the effects of farmers characteristics on poverty status in Delta State. International Journal of Humanities and Social Science Invention 2(5), pp. 11-16.
Umeh, J C, Ogah, J C and Ogbanje, C (2013). Socio-Economic characteristics and poverty among small-scale farmers in Apa Local Government area of Benue State, Nigeria. International Conference on Food and Agricultural Sciences 55 (20), pp. 106-111, doi: 10.7763/IPCBEE. Wijesuriya, W, Disssanayake, D M A P, Herath, H M L K and Gunaratne, P K K $S$ (2012). Constraints in sustainable smallholder rubber farming in the Moneragala district. Journal of the Rubber Research Institute of Sri Lanka 91, 61-73.

Address for correspondence: Mrs P G N Ishani, Research Officer, Agricultural Economics Unit, Rubber Research Institute of Sri Lanka, Dartonfield, Agalawatta, Sri Lanka,

e-mail:pgn.ishani@gmail.com 